\title{
SPECIFICS OF LEGISLATIVE REGULATION OF THE GAMBLING INDUSTRY IN UKRAINE
}

\section{Manzyuk V. V.}

\section{INTRODUCTION}

An important element in the development of a country as a democratic state is the formation of its legislative system based on the consideration of various social needs. However, situations, where the needs of a society are contrary to other established dogmas of this society, are somewhat complicated. This situation has developed in social relations in the field of gambling. On the one hand, the democratic values proclaimed by each state imply a variety of human rights, in our case, it is the right to freely dispose of one's time and money. However, the effects of gambling addiction leave a noticeable imprint on the moral values of society.

The gambling industry per se has always existed and the obsession with gambling has not decreased. At the same time, the danger of gambling for society has been recognized at all times. Despite its positive influence on the state treasury the state has nevertheless taken control of the gambling industry.

The relevance of the topic is predetermined by the fact that after declaring independence and having freed itself from the established socialist values and feeling a liberal taste of freedom, instead of effectively regulating social relations in the sphere of gambling Ukraine has chosen an easier path - the path of its total and abrupt prohibition.

At the current stage of information technology development, even legal levers are not able to properly regulate gambling relations, especially with regard to the organization of gambling on the Internet. Due to its properties, this sphere is not subject to total control.

\section{The history of gambling: social and moral factors of counteraction}

"Casino is an autonomous sub-universe among other worlds of life and socialization, the world of adventure among communication, entertainment, excitement and financial risk" Andreas Ziemann ${ }^{1}$

Society's attitude to gambling has always been ambiguous. For a long time, its existence has been subject to severe criticism, condemnation and persecution, it has been considered a "forbidden fruit". On the one hand,

\footnotetext{
${ }^{1}$ Ziemann Andreas. "Faites vos Jeux": eine kleine kiltursoziologie des casinos. Sociologia internationalis. Berlin: 44. Band, 2006. H. 2. S. 255.
} 
society has estimated gambling as economic fraud (since it does not produce and invest anything in economic turnover), and on the other hand, the gambling industry and its activities can significantly contribute to the budgets of the state and local governments ${ }^{2}$.

Gambling (from French jeux de hazard) is a game whose results, as opposed to commercial, are exclusively or mainly aleatory rather than depend on the player's adroitness or skill, provided that the bet is a thing whose gaining or losing cannot be treated indifferently on the part of players by means of their costs ${ }^{3}$.

Thus, the probability of easy enrichment and excitement has provided the basis of gambling prevalence.

Probability theory as a necessary feature of gambling is section of mathematics that studies the relationship between the probabilities of various events. The probability of occurrence of one of several incompatible events is equal to the sum of the probabilities of these events ${ }^{4}$. Probability theory as applicable to gambling (the Gambler's Ruin Problem ${ }^{5}$ ) was elaborately developed by H. Huygens in his treatise "On calculations in gambling" (1657). Thus, the author formed the concept of "mathematical expectation of winning" ${ }^{\text {. }}$.

However, it is not only easy money that attracts people to gambling but, most importantly, the excitement itself. The latter is considered a condition that causes passionate gambling which is accompanied by increased emotional tension ${ }^{7}$.

The passion for easy money in general and gambling in particular was inherent in humanity in ancient times. There is evidence of gambling obsession (dice) in the ancient Greeks (gambling was completely eliminated only in Sparta). The demoralizing influence of gambling was also recognized by Roman law. However, gambling was most developed in Germany. Up till the XIII-XIV centuries, the ancient German could lose not only his property but also his freedom in gambling (the loser, who had lost all his money and

${ }^{2}$ Опанасенко В.М. Чи існує економічна обгрунтованість легалізації азартних ігор на території України? Формування ринкових відносин в Україні. 2015. № 12 (175). С. 97.

3 Энциклопедический словарь Ф.А. Брокгауза и И.А. Ефрона / под ред. проф. И.Е. Андреевского. СПб: Семеновская Типо-Литографія (И.А. Ефрона), 1890. Т. 1. А-Алтай. C. 203-204.

${ }^{4}$ Энциклопедический словарь Ф.А. Брокгауза и И.А. Ефрона / нач. под ред. проф. И.Е. Андреевского; продолж. под ред. К.К. Арсеньева и О.О. Петрушевского. СПб: Издателькое Дело, 1901. Т. ХХXII. Тай-Термиты. С. 889.

${ }^{5}$ Гнеденко Б.В. Курс теории вероятностей : учеб. Изд. 6-е, перераб. и доп. М.: Наука, 1988. C. 35.

${ }^{6}$ Бернулли Я. О законе больших чисел / пер. с лат. Я.В. Успенского; под общ. ред Ю.В. Прохорова. М.: Наука, 1986. С. 85.

${ }^{7}$ Шевцов В.В. Карточная игра в России (конец XVI - начало XX в.): история игры и история общестава : монография / под ред. А.Н. Жеравиной, Э.Л. Львовой. Томск: Томский гос. ун-тет, 2005. С. 5. 
failed to pay, was sold into slavery). Subsequently, legislative restrictions began to emerge. However, the roulette game was encouraged since poor treasuries received heavy taxes on it.

Gambling houses first appeared in Italy in the XII century. In France, all gambling houses have been closed since 1839. In England, the law also provided for the protection of the losing party who was entitled to sue the opposing player.

However, Western European countries, forbidding gambling and gambling houses in their codes, did not invent reliable means against fraudsters and secret gambling houses, which, despite the high-profile police vigilance, held gambling games at fairs and public celebrations ${ }^{8}$.

Since the XVIII century, gambling has been transferred from a sphere governed solely by religious norms into a sphere of legal regulation, which is explained by their prevalence and the ineffectiveness of regulating this sphere only by church canons ${ }^{9}$.

The danger of gambling to the public has been recognized at all times, since not only the rich and wealthy but also the less wealthy and even the poor are easily addicted to gambling and sacrifice their hard-earned wealth in the pursuit of easy money. Thus, the state's primary duty was, at least, to ensure that such games did not take place publicly and did not attract a large number of people and would not adversely affect the population's material well-being ${ }^{10}$.

The current state of social relations in the field of gambling is developing somewhat differently. This is due to the fact that in addition to the moral and social barriers to the further development of the gambling industry, it has also been hampered by such a factor as the population's health.

Thus, a side effect of excitement is a disease caused by insatiable fascination, the person's propensity to gamble - gambling or ludomania (from Lat. ludus - game) ${ }^{11}$.

The ICD-10 Version of the International Classifier of Diseases, code F63.0 defines the pathological craving for gambling (pathological gambling). The essence of this disorder consists of frequent, repeated episodes of gambling that dominate the patient's life are detrimental to social, occupational, material, and family values and commitments.

8 Энциклопедический словарь Ф.А. Брокгауза и И.А. Ефрона / под ред. проф. И.Е. Андреевского. СПб: Семеновская Типо-Литографія (И.А. Ефрона), 1890. Т. 1. А-Алтай. C. 203-204.

${ }^{9}$ Сохан А.В. Азартные игры в России в середине XVI - в начале XXI вв. (историко-правовое исследование): автореф. дисс. ... канд. юрид. наук: 12.00.01. Н.Новгород, 2012. С. 16.

10 Энциклопедический словарь Ф.А. Брокгауза и И.А. Ефрона / под ред. проф. И.Е. Андреевского. СПб: Семеновская Типо-Литографія (И.А. Ефрона), 1890. Т. 1. А-Алтай. C. 203-204.

${ }^{11}$ Иванова О.А. Азартные игры как угроза общественной нравственности. Молодой учёный. 2013. № 9 (56). С. 299. 
A passionate gambling drive involves: excessive gambling by manic patients; aptitude for gambling and betting; gambling addiction in dissocial personality disorder (includes immoral, antisocial, asocial, psychopathic and sociopathic disorder) ${ }^{12}$.

The American Psychological Association (APA) provides the following definition of pathological gambling - an impulse-control disorder characterized by chronic, maladaptive wagering, leading to significant interpersonal, professional, or financial difficulties (gambling disorder) ${ }^{13}$. The term gambling disorder characterizes this behavioral pathology as a nonsubstance-related addiction. The main criteria for the disorder include persistent, recurrent gambling not related to manic episodes, along with significant impairment or distress. Associated behaviors may include betting increasing amounts of money, inability to limit or stop gambling, and preoccupation with gambling ${ }^{14}$.

Ludomania, as well as psychopathy, lies in the sphere of the subconscious. It is not treated with medication and is a chronic disease, which can be transmitted while communicating, when players incline their company to gamble ${ }^{15}$.

Thus, we conclude that gambling has been around since ancient times. The factors that contributed to the need for the legal regulation of this sphere are determined as follows:

1) state's preservation of the individual's family values and material well-being;

2) observance of religious dogmas in society (easy profit contradicts church ordinances since all amenities must be achieved through the individual's work);

3) prevention of social disorganization of the individual (gambling is often associated with such concomitant negative social phenomena as alcoholism, brigandism and idleness ${ }^{16}$ );

4) ensuring public health preservation.

Thus, each state faces a dilemma of choice: on the one hand, a complete ban on gambling as a negative social phenomenon in order to preserve moral values in society, the material well-being of the individual and the health of the

12 International Statistical Classification of Diseases and Related Health Problems $10^{\text {th }}$ Revision. World Health Organization. Version for 2016. URL: https://icd.who.int/browse10/ 2016/en\#/F63.0

${ }^{13}$ Dictionary of Psychology. DSM-IV-TR: American Psychological Association. Pathological gambling. URL: https://dictionary.apa.org/pathological-gambling (дата звернення: 26.09.2019).

${ }^{14}$ Dictionary of Psychology. DSM-IV-TR: American Psychological Association. Gambling disorder. URL: https://dictionary.apa.org/gambling-disorder (дата звернення: 26.09.2019).

${ }^{15}$ Бурдюг Д.Л., Синицына Л.В. Игровая зависимость в противоправном поведении. Юридическая психология. 2008. № 2. С. 35-38.

${ }^{16}$ Иванова О.А. Азартные игры как угроза общественной нравственности. Молодой учёный. 2013. № 9 (56). С. 299. 
population, and on the other hand, the development of a state based on liberal values, as well as a considerable amount of revenue to fill the state budget.

\section{The state of the gambling industry in Ukraine and prospects for its further legalization}

"If you can't beat them, join them ${ }^{17}$ "

Proverb

The state interest to gambling is conditioned, on the one hand, by the need to prevent instability in the economic circulation through transferring property from one person to another, and on the other hand - through receiving money for the budget in the form of taxes ${ }^{18}$. Currently, there are three models of government regulation of gambling in the world, which largely depend on the population's attitude to it:

1) a complete ban on gambling is characteristic of countries with severe religious prejudice against gambling;

2) the state allows only certain types of gambling and concentrates all gambling business in special places;

3) full legalization of gambling, however, under strict state control ${ }^{19}$.

In Ukraine, gambling left the legal path in 2009. The prerequisite for such a dramatic change in the legal regulation of gambling was the incident that happened on May 7, 2009, in Dnipropetrovsk. There was a fire at the "Metro Jackpot" gambling club that resulted in the deaths of 9 people (13 were seriously injured). The incident attracted considerable public attention. The next day the Ministry of Finance of Ukraine suspended all 205 licenses for conducting gambling activities ${ }^{20}$.

Experts at the site of the fire did not manage to finish their work when the perpetrators of the tragedy had already been "named" at the highest state level and loud political statements about the need to "restore order" in the field of gambling had been voiced. The tragedy in Dnipropetrovsk was extensively and skilfully "presented" to the people's deputies of Ukraine and to the whole Ukrainian society as the final convincing argument in favor of a

${ }^{17}$ Ammer Christine. The American Heritage dictionary of idioms. 1997. P. 513.

${ }^{18}$ Ярмонова Е.Н., Федина Н.А. История развития правового регулирования игр и пари. С. 2.

${ }^{19}$ Беззуб І. Чи потрібна Україні легалізація грального бізнесу: думки експертів. Центр досліджень сочіальних комунікачій НБУВ. URL: http://nbuviap.gov.ua/index.php? option=com_content\&view=article\&id=2218:chi-potribna-ukrajini-legalizatsiya-gralnogobiznesu\&catid=8\&Itemid=350 (дата звернення: 26.09.2019).

${ }^{20}$ Про зупинення дії ліцензій Міністерства фінансів України на провадження організації діяльності 3 проведення азартних ігор: Наказ Міністерства фінансів України від 8 травня 2009 року № 650. URL: https://zakon.rada.gov.ua/rada/show/v0650201-09 (дата звернення: 26.09.2019). 
categorical ban on gambling. On May 15, 2009, the Verkhovna Rada of Ukraine adopts the relevant Law of Ukraine in an extremely operational mode and then convincingly overcomes the President's veto ${ }^{21}$. As a result, Ukraine loses 3.5 billion hryvnias annually paid by gambling organizers to the budget ${ }^{22}$.

However, paragraph 1 in point 4 of the Final Provisions in the Law of Ukraine "On Prohibition of Gambling in Ukraine" 23 envisaged imposing on Cabinet of Ministers of Ukraine the duty to draft and submit for consideration of the Parliament of Ukraine law on gambling organization and conducting in the special gambling areas. However, in the last 10 years, the state authorities failed to pass legislation on the organization and activity of the gambling business. Relevant bills of $2015^{24}$ and $2016^{25}$ as well as the collateral draft law "On bookmaking activities" 26 were prepared and registered which, however, were withdrawn, as well as the relevant Cabinet of Ministers of Ukraine draft laws "On casino activity in Ukraine” of $2014^{27}$ and $2015^{28}$, which were not passed.

In 2011, criminal liability for engaging in gambling was introduced (Article 203-2 of the Criminal Code of Ukraine) ${ }^{29}$, and in 2016 the

21 Пояснювальна записка до проекту Постанови Верховної Ради України «Про утворення Тимчасової слідчої комісії Верховної Ради України з питань розслідування обставин, висвітлених у засобах масової інформації щодо порушень, допущених у ході досудового слідства та судового розгляду справи про пожежу в залі гральних автоматів у Дніпропетровську, яка сталася 07 травня 2009 року та призвела до загибелі 9 осіб». URL: http://w1.c1.rada.gov.ua/pls/zweb2/webproc4_1?id=\&pf3511=38833 (дата звернення: 26.09.2019).

22 Пропозиції Президента України до закону України «Про заборону грального бізнесу в Україні» від 04.06.2009 p. URL: http://w1.c1.rada.gov.ua/pls/zweb2/webproc4_ 1 ?pf3511=34855 (дата звернення: 26.09.2019).

${ }^{23}$ Про заборону грального бізнесу в Україні: Закон України від 15 травня 2009 року № 1334-VI. Голос Украӥни. № 116.

${ }^{24}$ Про детінізацію ринку азартних ігор та забезпечення доходами бюджету з метою виконання соціальних зобов'язань: Проект Закону від 11 грудня 2015 року № 3632. URL: http://w1.c1.rada.gov.ua/pls/zweb2/webproc4_1?pf3511=57390 (дата звернення: 26.09.2019).

${ }^{25}$ Про детінізацію ринку азартних ігор та забезпечення доходами бюджету з метою виконання соціальних зобов'язань: Проект Закону від 13 травня 2016 року № 4663. URL: http://w1.c1.rada.gov.ua/pls/zweb2/webproc4_1?pf3511=59089 (дата звернення: 26.09.2019).

${ }^{26}$ Про букмекерську діяльність: Проект Закону від 03 березня 2019 року № 2268. URL: http://w1.c1.rada.gov.ua/pls/zweb2/webproc4_1?pf3511=54231 (дата звернення: 26.09.2019).

${ }^{27}$ Про діяльність казино в Україні: Проект Закону від 28 січня 2015 року № 1869. URL: http://w1.c1.rada.gov.ua/pls/zweb2/webproc4_1?pf3511=53064 (дата звернення: 26.09.2019).

${ }^{28}$ Про діяльність казино в Україні: Проект Закону від 22 грудня 2014 року № 1571. URL: http://w1.c1.rada.gov.ua/pls/zweb2/webproc4_1?id=\&pf3511=53729 (дата звернення: 26.09.2019).

${ }^{29}$ Про внесення змін до деяких законодавчих актів України щодо удосконалення законодавства про заборону грального бізнесу в Україні: Закон України від 22 грудня 2010 року № 2852- VI. Голос Украӥни. № 5. 
confiscation of gaming equipment was excluded from the sanction of this article ${ }^{30}$.

The legal alternative to illegal gambling in Ukraine has been lotteries ${ }^{31}$, where the only monopoly belongs to the state ${ }^{32}$.

In this regard, the logical questions arise: Cui bono? Cui prodest? i.e. who benefits? ${ }^{33}$ The state, which could receive income from tax deductions from gambling establishments and granting licenses, instead conducts an unclear fight against them, thereby facilitating the existence of illegal gambling establishments and shadowing the income from the latter.

In order to unshadow the economy, it is necessary to create favorable conditions for the functioning of various forms of business at the legislative level $^{34}$. The European standards, strived for by Ukrainian society, require a clear legal regulation of all spheres of life that could effectively combat the features of the post-Soviet societies' development.

This pertains to a great extent to gambling as a prospect for tourism development in Ukraine. A thorough analysis of the general and local European legislation and the adoption of relevant legislation in Ukraine will allow to gain the positive effect of gambling legalization, to form an optimal model of such legalization which will benefit the Ukrainian economy, fill the budget, and change the attitude of domestic society to this sphere of economy $^{35}$. This viewpoint is also supported by the fact that the ban on gambling in some countries, with prudent legislative regulation, one way or the other engenders its rise in other countries ${ }^{36}$ (for example, a junket - trip has recently gained popularity ${ }^{37}$, which is a cultural and entertaining program with obligatory visits to gambling establishments funded by the gambling

${ }^{30}$ Про внесення змін до Кримінального та Кримінального процесуального кодексів України щодо виконання рекомендацій, які містяться у шостій доповіді Європейської комісії про стан виконання Україною Плану дій щодо лібералізації Європейським Союзом візового режиму для України, стосовно удосконалення процедури арешту майна та інституту спеціальної конфіскації: Закон України від 18 лютого 2016 року № 1019-VIII. Відомості Верховної ради Украӥни. 2016. № 11. Ст. 127.

31 Лиськов М.О. Нормативно-правове адміністрування лотерейної сфери. Прикарпатський юридичний вісник. 2016. Вип. 5 (14). С. 80.

32 Про державні лотереї в Україні: Закон України від 6 вересня 2012 року № 5204-VI. Офіційний вісник України. 2012. № 76. Ст. 3068.

${ }^{33}$ A Dictionary of Quotations, in most frequent use. The second edition, revised and enlarge. London: G.G. and J. Robinson, 1798. 234 p.

${ }^{34}$ Молчанов Д. Удосконалення адміністративно-правового регулювання фінансового контролю та моніторингу як засобів протидії тонізації економіки України з урахуванням міжнародного досвіду. Підприємництва, господарство і право. 2017. Вип. 10. С. 121.

${ }^{35}$ Гищук Р.Н., Бойко И.Д. Особенности функционирования игорного бизнеса в европейских странах и их опыт в контексте развития туризма в Украине. Світове господарство і міжнародні економічні відносини. 2017. Вип. I-II (65-66). С. 267.

${ }^{36}$ Ibid. C. 259.

${ }^{37}$ James C. Makens, John T. Bowen. Junket reps and casino marketing. The Cornell Hotel and Restaurant Administration Quartery. 1994. Vol. 35. Issue 5. P. 63-69. 
establishments themselves, in particular, casinos). This, in turn, stimulated the development of tourism in post-Soviet countries.

Separate standards in the field of gambling were also elaborated by the European Parliament. Thus, Article 10 of Directive 2005/60 / EC envisages that Member States shall require that all casino customers be identified and their identity verified if they purchase or exchange gambling chips with a value of EUR 2000 or more. Besides, Member States shall provide that casinos be licensed in order to operate their business legally and the competent authorities shall have enhanced supervisory powers, notably the possibility to conduct on-site inspections ${ }^{38}$. As to organizers themselves, the Directive requires that the persons who effectively direct or will direct the business of such entities and the beneficial owners of such entities are fit and proper persons. The criteria for determining whether or not a person is fit and proper should be established in conformity with national law (at least, such criteria should reflect the need to protect such entities from being misused by their managers or beneficial owners for criminal purposes).

Thus, after the categorical ban on gambling, the number of cases in the courts of Ukraine increased. The cases of business entities (organizers of gambling business) became widespread, in particular: the return of the superfluously paid sum from the state budget for the pre-term license revocation, which was paid for several years in advance ${ }^{39}$; compensation for real damages related to the license revocation (the amount of the license value for the unused period of its validity, the cost of gaming equipment, including depreciation fee, the cost of the registrars of the settlement transaction, the cost of advertising, compensation to employees for unused vacation, etc $)^{40}$; termination of the loan agreement, since the funds were provided to the plaintiff for the development of gambling business, thereby the plaintiff was deprived of the anticipated revenue at the conclusion of the loan agreement ${ }^{41}$.

In each case related to the violation of property rights, it must be determined whether the person concerned should incur a disproportionate and undue burden in connection with the actions or inactivity of the State ${ }^{42}$.

${ }^{38}$ Directive 2005/60/EC of the European Parliament and of the Council on the prevention of the use of the financial system for the purpose of money laundering and terrorist financing of 26 October 2005. Official Journal of the European Union. 2005. L 309/15.

${ }^{39}$ Постанова Верховного Суду України від 25 квітня 2017 року № 2a-12490/10/1370.

URL: http://www.reyestr.court.gov.ua/Review/66775066 (дата звернення: 26.09.2019).

40 Постанова Вищого господарського суду України від 22 вересня 2010 року № 41/575. URL: http://www.reyestr.court.gov.ua/Review/11413915 (дата звернення: 26.09.2019).

${ }^{41}$ Постанова Вищого господарського суду України від 01 червня 2010 року № 42/254-09. URL: http://www.reyestr.court.gov.ua/Review/10000135 (дата звернення: 26.09.2019).

42 Judgment of the European Court of Human Rights in the case «Ahmet Yildirim v. Turkey» on December 18, 2012 (Application № 3111/10). URL: http://hudoc.echr.coe.int/ rus?i=001-115705 (дата звернення: 26.09.2019). 
Analysing the litigation practice, the author concludes that national courts have always sided with the state, motivating the measures taken by the authorities within their own powers ${ }^{43}$, and the losses incurred by the business entities are covered by their entrepreneurial risk ${ }^{44}$.

For the first time, the European Court of Human Rights (hereinafter referred to as the ECtHR) has come to protect the rights of business entities organizers of gambling. The latter notes that the solutions reached by the legislature cannot be beyond the scrutiny of the ECtHR which should examine carefully the arguments taken into consideration during the legislative process and leading to the choices that have been made by the legislature and to determine whether a fair balance has been struck between the competing interests of the State and those directly affected by those legislative choices ${ }^{45}$.

In the case "of Svit Rozvag, TOV and Others v. Ukraine" has found a number of violations related to the adoption of the Law of Ukraine "On Prohibition of Gambling of Ukraine" (hereinafter - the Law).

has found a violation of Article 1 of Protocol No. 1 not on account of the prohibition of gambling as such but only on account of the manner in which that measure was adopted and implemented, notably the lack of a meaningful transitional period. Therefore, not all of the applicant company's losses due to the discontinuation of its gambling business need to give rise to compensation.

Thus, with the revocation of the gambling license, the right of ownership of the organizers of the latter was breached (violation of Article 1 of Protocol No. 1 to the Convention for the Protection of Human Rights and Fundamental Freedoms ${ }^{47}$ ), in particular due to the lack of any compensatory measures, even in respect of the direct costs imposed by the State itself. There has accordingly been a violation of Article 1 of Protocol No. 1 on account of the manner in which the applicants' licenses were revoked.

Another breach was the lack of a meaningful transition period for business entities, which theoretically constituted 40 days. However, the

43 Постанова Вищого адміністративного суду України від 26 листопада 2015 року № K/800/51343/14. URL: http://www.reyestr.court.gov.ua/Review/53927584 (дата звернення: 26.09.2019).

44 Постанова Вищого господарського суду України від 01 червня 2010 року № 42/254/09. URL: http://www.reyestr.court.gov.ua/Review/10000135 (дата звернення: 26.09.2019).

45 Judgment of the European Court of Human Rights in the case «Garib v. the Netherlands» on November 6, 2017 (Application № 43494/09). URL: http://hudoc.echr.coe.int/rus?i= 001-177406 (дата звернення: 26.09.2019).

${ }^{46}$ Judgment of the European Court of Human Rights in the case «Svit Rozvag, TOV and Others v. Ukraine» on June 27, 2019 (Application № 13290/11). URL: http://hudoc.echr.coe.int/ rus?i=001-193994 (дата звернення: 26.09.2019).

${ }^{47}$ Протокол до Конвенції про захист прав людини і основоположних свобод від 20 березня 1952. Офіційний вісник Украӥни. 2006. № 32. Ст. 2372. 
Cabinet of Ministers of Ukraine, by virtue of its powers, terminated the applicant's license, and therefore, in essence, there was no transitional period for him. This was further exacerbated by the fact that the gambling policy changed especially rapidly: the previous rigid policies were replaced by a total ban in just 2 months. The Law itself was designed as a temporary ban and required the Cabinet of Ministers of Ukraine to submit proposals on the regulation of the gambling industry, which was never the case.

The bills ${ }^{48}$, referred to by the government are a private initiative and there are no indications that they have ever been supported by the authorities. Failure to promise to introduce this legislation created uncertainty, placing an additional burden on the applicant company. And the vague promise that the measure would be temporary and would later be replaced by a policy of restricted gambling areas had only added an element of uncertainty to the situation and demonstrated inconsistency in internal government policy.

A norm is "foreseeable" when it affords a measure of protection against arbitrary interferences by the public authorities ${ }^{49}$. The expression "prescribed by law" requires firstly that the impugned measure should have some basis in domestic law; however, it also refers to the quality of the law in question, requiring that it should be accessible to the person concerned, who must moreover be able to foresee its consequences, and that it should be compatible with the rule of law ${ }^{50}$.

The ECtHR resolution is a special form of precedent created by a supranational body and is binding upon member states of the Convention ${ }^{51}$. Unfortunately, the Convention for the Protection of Human Rights and Fundamental Freedoms does not provide for the institution of an actio popularis, and the court itself cannot decide the case in the interests of public order ${ }^{52}$.

${ }^{48}$ Про детінізацію ринку азартних ігор та забезпечення доходами бюджету з метою виконання соціальних зобов’язань: Проект Закону від 11 грудня 2015 року № 3632. URL: http://w1.c1.rada.gov.ua/pls/zweb2/webproc4_1?pf3511=57390 (дата звернення: 26.09.2019); Про детінізацію ринку азартних ігор та забезпечення доходами бюджету 3 метою виконання соціальних зобов’язань: Проект Закону від 13 травня 2016 року № 4663. URL: http://w1.c1.rada.gov.ua/pls/zweb2/webproc4_1?pf3511=59089 (дата звернення: 26.09.2019).

49 Judgment of the European Court of Human Rights in the case «Lekić v. Slovenia» on December 4, 2015 (Application № 36480/07). URL: http://hudoc.echr.coe.int/rus?i=001-188268 (дата звернення: 26.09.2019).

50 Judgment of the European Court of Human Rights in the case "Ahmet Yildirim v. Turkey” on December 18, 2012 (Application № 3111/10). URL: http://hudoc.echr.coe.int/rus?i= 001-115705 (дата звернення: 26.09.2019).

${ }^{51}$ Новіков Д.В. Захист права власності Європейським судом з прав людини: досвід для правової системи та судової практики України: дис. ... канд. юрид. наук: спец. 12.00.03. Київ, 2018. С. 29.

52 Judgment of the European Court of Human Rights in the case "Roman Zakharov v. Russia” on December 11, 2018 (Application № 47143/06). URL: http://hudoc.echr.coe.int/ eng?i=001-159324 (дата звернення: 26.09.2019). 


\section{Features of legal regulation of Internet gambling}

It is relevant for any state that the Internet has now become one of the principal means by which individuals exercise their right to freedom to receive and impart information and ideas, providing as it does essential tools for participation in activities and discussions concerning political issues and issues of general interest ${ }^{53}$. Therefore, user-generated expressive activity on the Internet provides an unprecedented platform for the exercise of freedom of expression ${ }^{54}$.

At the current stage of information technology development and many states' focus on cybersecurity development, the regulation of online gambling, in particular, online casinos, is the subject of heated discussion. Such concern arises because of the unregulated nature of the field, which, because of its properties, is not subject to total control.

In the case of virtual gambling, there is no specific equipment that is subject to certification. Here we deal with software that is not licensed by anyone. There is not even a directory of games that can be used to check the programs for quality, for the presence of fraudulent elements, as well as to make sure that the payout is guaranteed ${ }^{55}$.

The attractiveness of online casinos for business entities lies in the fact that its organization requires only a gaming server and electronic transfer accounts. At the same time, there is no need to have premises, equipment, license for this type of activity, personnel and to bear the whole complex of accompanying expenses. There occurs an involvement of Internet users, mostly young people, in gambling ${ }^{56}$.

It should be noted that for the most part, states that have legalized gambling, however, have restricted its age category, typically 18 or 21 years old. In countries where gambling functions only as a shadow economy, and its identification is a matter of time, it is more difficult to find the latter in the "worldwide web”. Online casino operators may not register their activities, place their server under the jurisdiction of a foreign country, use international domain zones, or operate through offshore zones.

To regulate such online business, A.Sh. Kazbekov offers P. R. China's experience that filters unwanted internet content. While this is contrary to the

53 Judgment of the European Court of Human Rights in the case "Cengiz and Others v. Turkey" on December 1, 2016 (Applications nos. 48226/10 and 14027/11). URL: http:/hudoc.echr.coe.int/ eng?i=001-159188 (дата звернення: 26.09.2019).

54 Judgment of the European Court of Human Rights in the case «Delfi AS v. Estonia» on June 16, 2015 (Application № 64569/09). URL: http://hudoc.echr.coe.int/rus?i=001-155105 (дата звернення: 26.09.2019).

${ }^{55}$ Каргина Л.А., Камачо Чаваррия М.Д. Развитие интернет-офшоров в Коста-Рике. Вестник Академии. 2010. № 2. С. 96.

${ }^{56}$ Казбеков А.Ш. Современные тенденции теневого игорного бизнеса, организованного с использованием сети «Интернет». Вестник Нижегородской академии МВД России. 2011. № 2 (15). C. 219. 
liberal views of the majority, few will object to restricting access to sites with obscene content and / or malicious software ${ }^{57}$.

The features of gambling are the purpose of profit, where the source of the latter is the game ${ }^{58}$. The gambling business itself is based on a combination of two interdependent tasks - the acquisition of material goods and the satisfaction of their needs, which consist in the desire to achieve a certain stressful state ${ }^{59}$. Thus, one of the hallmarks of gambling is its renumeration as a prerequisite for risk ${ }^{60}$, as well as its grounding in the theory of probability which is not accepted by gamblers. APA names it a gambler's fallacy, i.e. a failure to recognize the independence of chance events, leading to the mistaken belief that one can predict the outcome of a chance event on the basis of the outcomes of past chance events. For example, a person might think that the more often a tossed coin comes up heads, the more likely it is to come up tails in subsequent tosses, although each coin toss is independent of any other and the true probability of the outcome of any toss is still just ${ }^{61}$. In this regard, both gamblers and new players fall into debt bondage, taking on the available loans provided by the organizers of online casinos. When issuing such loans, the latter are inappropriate to check the income of everyone, primarily in the temporal aspect, where the main role is played by chance, and therefore "every minute matters". The author proposes to regulate such relations in Ukraine as follows.

Part 2 of Art. 36 of the Civil Code of Ukraine ${ }^{62}$ envisages that the court may restrict a natural person's legal capability if he/she abuses alcohol, drugs, toxic substances etc. whereby bringing himself/herself or his/her family as well as other persons he/she has to maintain by the law into hard circumstances.

According to the author, it would be advisable to establish the Unified Ukrainian State Register of Incapacitated Persons and Persons Restricted in Legal Capability. Access to the latter will be granted, in particular, to licensed organizers of game zones, who will be obliged to check the register of persons requesting the credit for participation in the online game

${ }^{57}$ Казбеков А.Ш. Современные тенденции теневого игорного бизнеса, организованного с использованием сети «Интернет». Вестник Нижегородской академии МВД России. 2011. № 2 (15). С. 220.

${ }^{58}$ Васильєва Д.О. Кримінологічне поняття грального бізнесу. Науковий вісник публічного та приватного права. 2017. Вип. 3. С. 158.

${ }^{59}$ Мулявка Д.Г. Гармонізація правового регулювання азартних ігор в Україні та ЄС. Юридичний науковий електронний журнал. 2016. № 1. С. 62.

${ }^{60}$ Іванова О.А. Уголовная ответственность за незаконные организацию и проведение азартных игр: дисс. ... канд. юрид. наук: 12.00.08. Саратов, 2016. С. 217-218.

${ }^{61}$ Dictionary of Psychology. DSM-IV-TR: American Psychological Association. Gambler's fallacy. URL: https://dictionary.apa.org/gamblers-fallacy (дата звернення: 26.09.2019).

${ }^{62}$ Цивільний кодекс України від 16 січня 2003 року № 435-IV. Відомості Верховної Ради Украӥни. 2003. № 40. Ст. 356. 
(in accordance with the retention of such information). In case of noncompliance with this norm, the organizers will be held administratively liable.

\section{CONCLUSIONS}

The retrospection of the gambling industry allows us to conclude that the factors contributing to the need for legal regulation in this field include:

- social (state's preservation of the individual's family values and material well-being, prevention of social disorganization of the individual);

- moral (demoralizing impact of gambling on the population);

- religious (easy profit contradicts church ordinances since all amenities must be achieved through the individual's work);

- health care (prevention of pathological gambling);

However, each state faces a dilemma of choice: on the one hand, a complete ban on gambling as a negative social phenomenon in order to preserve moral values in society, the individual's material well-being and the health of the population, and on the other hand, the development of a state based on liberal values, as well as a considerable amount of revenue to fill the state budget.

On the example of Ukraine, it can be noted that the total and drastic ban on gambling, although favorably received by the population, nevertheless led only to global litigation in national courts. Moreover, the authorities' inactivity in regulating public relations in this sphere only strengthened the public opinion as to the prolongation of their interests by the state authorities. In this regard, in 10 years the organizers of the gambling business have the right for the fair legal redress.

\section{SUMMARY}

The article reveals the features of legal regulation of the gambling industry through the retrospection of the research into gambling issues. The main factors leading to the need for government regulation of the gambling industry are analysed.

The article examines the consequences of an abrupt and total ban on gambling on the example of Ukraine. The conclusions are drawn on the negative consequences that have arisen as a result of a dramatic change in the situation at the legislative level and the inaction of state authorities in regulating relations in the field of gambling. This governmental activity violated not only the rights and freedoms of economic entities organizers of gambling but also led to the shadowing of the gambling market. Moreover, the abrupt and total state interference with the sphere of private life was not commensurate and resulted in an imbalance between public and private interests.

The study proves the necessity of legal regulation of public relations in the sphere of the gambling industry and the direction of the state policy for 
the legalization of the latter under state control. The rapid development of online gambling is also analysed. The article offers recommendations for regulating this segment at the legislative level in Ukraine.

\section{REFERENCES}

1. Ziemann Andreas. "Faites vos Jeux": eine kleine kiltursoziologie des casinos. Sociologia internationalis. Berlin: 44. Band, 2006. H. 2. S. 253-274.

2. Опанасенко В.М. Чи існує економічна обгрунтованість легалізації азартних ігор на території України? Формування ринкових відносин в Україні. 2015. № 12 (175). С. 97-100.

3. Энциклопедический словарь Ф.А. Брокгауза и И.А. Ефрона / под ред. проф. И.Е. Андреевского. СПб: Семеновская Типо-Литографія (И.А. Ефрона), 1890. Т. 1. А-Алтай. 495 с.

4. Энциклопедический словарь Ф.А. Брокгауза и И.А. Ефрона / нач. под ред. проф. И.Е. Андреевского; продолж. под ред. К.К. Арсеньева и О.О. Петрушевского. СПб: Издателькое Дело, 1901. Т. XXXII. ТайТермиты. 960 с.

5. Гнеденко Б.В. Курс теории вероятностей : учеб. Изд. 6-е, перераб. и доп. М.: Наука, 1988. 447 с.

6. Бернулли Я. О законе больших чисел / пер. с лат. Я.В. Успенского; под общ. ред Ю.В. Прохорова. М.: Наука, 1986. 176 с.

7. Шевцов В.В. Карточная игра в России (конец XVI - начало $\mathrm{XX}$ в.): история игры и история общестава : монография / под ред. А.Н. Жеравиной, Э.Л. Львовой. Томск: Томский гос. ун-тет, 2005. 244 с.

8. Сохан А.В. Азартные игры в России в середине XVI - в начале XXI вв. (историко-правовое исследование): автореф. дисс. ... канд. юрид. наук: 12.00.01. Н. Новгород, 2012. 30 с.

9. Иванова О.А. Азартные игры как угроза общественной нравственности. Молодой учёный. 2013. № 9 (56). С. 299-302.

10. International Statistical Classification of Diseases and Related Health Problems $10^{\text {th }}$ Revision. World Health Organization. Version for 2016. URL: https://icd.who.int/browse10/2016/en\#/F63.0/.

11. Dictionary of Psychology. DSM-IV-TR: American Psychological Association. Pathological gambling. URL: https://dictionary.apa.org/ pathological-gambling (дата звернення: 26.09.2019).

12. Dictionary of Psychology. DSM-IV-TR: American Psychological Association. Gambling disorder. URL: https://dictionary.apa.org/gamblingdisorder (дата звернення: 26.09.2019).

13. Бурдюг Д.Л., Синицына Л.В. Игровая зависимость в противоправном поведении. Юридическая психология. 2008. № 2. С. 35-38.

14. Ammer Christine. The American Heritage dictionary of idioms. 1997. P. 513. 
15. Ярмонова Е.Н., Федина Н.А. История развития правового регулирования игр и пари. Современные проблемы науки и образования. 2015. № 1. С. 125-129.

16. Беззуб І. Чи потрібна Україні легалізація грального бізнесу: думки експертів. Центр досліджень соціальних комунікацій НБУВ. URL: http://nbuviap.gov.ua/index.php?option=com_content\&view= article\&id=2218: chi-potribna-ukrajini-legalizatsiya-gralnogobiznesu\&catid=8\&Itemid=350 (дата звернення: 26.09.2019).

17. Про зупинення дії ліцензій Міністерства фінансів України на провадження організації діяльності 3 проведення азартних ігор: Наказ Міністерства фінансів України від 8 травня 2009 року № 650 . URL: https://zakon.rada.gov.ua/rada/show/v0650201-09 (дата звернення: 26.09.2019).

18. Пояснювальна записка до проекту Постанови Верховної Ради України «Про утворення Тимчасової слідчої комісії Верховної Ради України з питань розслідування обставин, висвітлених у засобах масової інформації щодо порушень, допущених у ході досудового слідства та судового розгляду справи про пожежу в залі гральних автоматів у Дніпропетровську, яка сталася 07 травня 2009 року та призвела до загибелі 9 осіб». URL: http://w1.c1.rada.gov.ua/pls/zweb2/ webproc4_1?id=\&pf3511=38833 (дата звернення: 26.09.2019).

19. Пропозиції Президента України до закону України «Про заборону грального бізнесу в Україні» від 04.06.2009 p. URL: http://w1.c1.rada.gov.ua/pls/zweb2/webproc4_1?pf3511=34855 (дата звернення: 26.09.2019).

20. Про заборону грального бізнесу в Україні: Закон України від 15 травня 2009 року № 1334-VI. Голос Украӥни. № 116.

21. Про детінізацію ринку азартних ігор та забезпечення доходами бюджету з метою виконання соціальних зобов'язань: Проект Закону від 11 грудня 2015 року № 3632. URL: http://w1.c1.rada.gov.ua/pls/ zweb2 /webproc4_1?pf3511=57390 (дата звернення: 26.09.2019).

22. Про детінізацію ринку азартних ігор та забезпечення доходами бюджету з метою виконання соціальних зобов'язань: Проект Закону від 13 травня 2016 року № 4663. URL: http://w1.c1.rada.gov.ua/pls/ zweb2/webproc4 1? pf3511=59089 (дата звернення: 26.09.2019).

23. Про букмекерську діяльність: Проект Закону від 03 березня 2019 року № 2268. URL: http://w1.c1.rada.gov.ua/pls/zweb2/webproc4_ 1?pf3511=54231 (дата звернення: 26.09.2019).

24. Про діяльність казино в Україні: Проект Закону від 28 січня 2015 року № 1869. URL: http://w1.c1.rada.gov.ua/pls/zweb2/webproc4_ 1?pf3511=53064 (дата звернення: 26.09.2019). 
25. Про діяльність казино в Україні: Проект Закону від 22 грудня 2014 року № 1571. URL: http://w1.c1.rada.gov.ua/pls/zweb2/webproc4_ 1 ? $\mathrm{id}=\& \mathrm{pf3511}=53729$ (дата звернення: 26.09.2019).

26. Про внесення змін до деяких законодавчих актів України щодо удосконалення законодавства про заборону грального бізнесу в Україні: Закон України від 22 грудня 2010 року № 2852- VI. Голос України. № 5.

27. Про внесення змін до Кримінального та Кримінального процесуального кодексів України щодо виконання рекомендацій, які містяться у шостій доповіді Європейської комісії про стан виконання Україною Плану дій щодо лібералізації Європейським Союзом візового режиму для України, стосовно удосконалення процедури арешту майна та інституту спеціальної конфіскації: Закон України від 18 лютого 2016 року № 1019-VIII. Відомості Верховної ради Украӥни. 2016. № 11. Ст. 127.

28. Лиськов М.О. Нормативно-правове адміністрування лотерейної сфери. Прикарпатський юридичний вісник. 2016. Вип. 5 (14). С. 77-80.

29. Про державні лотереї в Україні: Закон України від 6 вересня 2012 року № 5204-VI. Офіиійний вісник Украӥни. 2012. № 76. Ст. 3068.

30. A Dictionary of Quotations, in most frequent use. The second edition, revised and enlarge. London: G.G. and J. Robinson, 1798. 234 p.

31. Молчанов Д. Удосконалення адміністративно-правового регулювання фінансового контролю та моніторингу як засобів протидії тінізації економіки України з урахуванням міжнародного досвіду. Підприємництва, господарство і право. 2017. Вип. 10. С. 117-122.

32.Гищук Р.Н., Бойко И.Д. Особенности функционирования игорного бизнеса в европейских странах и их опыт в контексте развития туризма в Украине. Світове господарство і міжнародні економічні відносини. 2017. Вип. I-II (65-66). С. 258-270.

33. James C. Makens, John T. Bowen. Junket reps and casino marketing. The Cornell Hotel and Restaurant Administration Quartery. 1994. Vol. 35. Issue 5. P. 63-69.

34. Directive 2005/60/EC of the European Parliament and of the Council on the prevention of the use of the financial system for the purpose of money laundering and terrorist financing of 26 October 2005. Official Journal of the European Union. 2005. L 309/15.

35. Постанова Верховного Суду України від 25 квітня 2017 року № 2a-12490/10/1370. URL: http://www.reyestr.court.gov.ua/Review/ 66775066 (дата звернення: 26.09.2019).

36. Постанова Вищого господарського суду України від 22 вересня 2010 року № 41/575. URL: http://www.reyestr.court.gov.ua/Review/ 11413915 (дата звернення: 26.09.2019). 
37. Постанова Вищого господарського суду України від 01 червня 2010 року № 42/254-09. URL: http://www.reyestr.court.gov.ua/Review/ 10000135 (дата звернення: 26.09.2019).

38. Judgment of the European Court of Human Rights in the case «Ahmet Yildirim v. Turkey» on December 18, 2012 (Application № 3111/10). URL: http://hudoc.echr.coe.int/rus?i=001-115705 (дата звернення: 26.09.2019).

39. Постанова Вищого адміністративного суду України від 26 листопада 2015 року № K/800/51343/14. URL: http://www.reyestr.court.gov.ua/ Review/53927584 (дата звернення: 26.09.2019).

40. ECHR in the case "Garib v. the Netherlands" on November 6, 2017 (Application № 43494/09). URL: http://hudoc.echr.coe.int/rus?i=001-177406 (дата звернення: 26.09.2019).

41.ECHR in the case "Svit Rozvag, TOV and Others v. Ukraine" on June 27, 2019 (Application № 13290/11). URL: http://hudoc.echr.coe.int/ rus? $\mathrm{i}=001-193994$ (дата звернення: 26.09.2019).

42. Протокол до Конвенції про захист прав людини і основоположних свобод від 20 березня 1952. Офіційний вісник Украӥни. 2006. № 32. Ст. 2372.

43. ECHR in the case «Lekić v. Slovenia» on December 4, 2015 (Application № 36480/07). URL: http://hudoc.echr.coe.int/rus?i=001-188268 (дата звернення: 26.09.2019).

44. Новіков Д.В. Захист права власності Європейським судом з прав людини: досвід для правової системи та судової практики України: дис. ... канд. юрид. наук: спец. 12.00.03. Київ, 2018. 211 с.

45. ECHR in the case "Roman Zakharov v. Russia» on December 11, 2018 (Application № 47143/06). URL: http://hudoc.echr.coe.int/eng?i= 001-159324 (дата звернення: 26.09.2019).

46. ECHR in the case «Cengiz and Others v. Turkey» on December 1, 2016 (Applications nos. 48226/10 and 14027/11). URL: http://hudoc.echr.coe.int/ eng?i=001-159188 (дата звернення: 26.09.2019).

47. ECHR in the case «Delfi AS v. Estonia» on June 16, 2015 (Application № 64569/09). URL: http://hudoc.echr.coe.int/rus?i=001-155105 (дата звернення: 26.09.2019).

48. Каргина Л.А., Камачо Чаваррия М.Д. Развитие интернет-офшоров в Коста-Рике. Вестник Академии. 2010. № 2. С. 95-96.

49. Казбеков А.Ш. Современные тенденции теневого игорного бизнеса, организованного с использованием сети «Интернет». Вестник Нижегородской академии МВД России. 2011. № 2 (15). С. 218-221.

50. Васильєва Д.О. Кримінологічне поняття грального бізнесу. Науковий вісник публічного та приватного права. 2017. Вип. 3. С. 156-170.

51. Мулявка Д.Г. Гармонізація правового регулювання азартних ігор в Україні та ЄС. Юридичний науковий електронний журнал. 2016. № 1. C. 58-61. 
52. Іванова О.А. Уголовная ответственность за незаконные организацию и проведение азартных игр: дисс. ... канд. юрид. наук: 12.00.08. Саратов, 2016. $270 \mathrm{c.}$

53. Dictionary of Psychology. DSM-IV-TR: American Psychological Association. Gambler's fallacy. URL: https://dictionary.apa.org/gamblersfallacy (дата звернення: 26.09.2019).

54. Цивільний кодекс України від 16 січня 2003 року № 435-IV. Відомості Верховної Ради Украӥни. 2003. № 40. Ст. 356.

\section{Information about the author:} Manzyuk V. V.,

Candidate of Juridical Sciences, Associate Professor, Associate Professor at the Department of Economic Law, Uzhhorod National University 26, Kapitulna str., Uzhhorod, Ukraine 